\title{
Germination and tolerance of cowpea (Vigna unguiculata) cultivars to water stress
}

\author{
Emanoela P. de Paiva ${ }^{1}$, Francisco V. da S. Sá ${ }^{2}$, Salvador B. Torres ${ }^{1}$, \\ Marcos E. B. Brito ${ }^{3}$, Romulo C. L. Moreira ${ }^{4}$ \& Luderlândio de A. Silva ${ }^{4}$ \\ ${ }^{1}$ Universidade Federal Rural do Semi-Árido/Centro de Ciências Agrárias/Departamento de Ciências Agronômicas e Florestais. Mossoró, RN. E-mail: \\ emanuelappaiva@hotmail.com (Corresponding author) - ORCID: 0000-0003-4510-9205; sbtorres@ufersa.edu.br - ORCID: 0000-0003-0668-3327 \\ ${ }^{2}$ Universidade Federal Rural do Semi-Árido/Centro de Ciências Agrárias/Programa de Pós-Graduação em Manejo de Solo e Água. Mossoró, RN. E-mail: \\ vanies_agronomia@hotmail.com - ORCID: 0000-0001-6585-8161 \\ ${ }^{3}$ Universidade Federal de Sergipe/Centro de Ciências Agrárias do Sertão/Núcleo de Graduação em Educação em Ciências Agrárias e da Terra. Nossa \\ Senhora da Glória, SE E-mail: marcoseric@ufs.br - ORCID: 0000-0001-9087-3662 \\ ${ }^{4}$ Universidade Federal de Campina Grande/Centro de Tecnologia e Recursos Naturais/Unidade Acadêmica de Engenharia Agrícola. Campina Grande, \\ PB. E-mail: romulocarantino@gmail.com - ORCID: 0000-0002-4079-4939; luderlandioandrade@gmail.com - ORCID: 0000-0001-9496-5820
}

\section{Key words:}

initial growth

polyethylene glycol

osmotic potential

\begin{abstract}
A B S T R A C T
The objective of this study was to evaluate the tolerance of cowpea cultivars to water stress, during seed germination and seedling establishment. For this, a completely randomized experimental design was used in a factorial scheme consisting of nine cultivars of cowpea (BRS Guariba, BRS Potengi, BRS Itaim, BRS 17 Gurguéia, BRS Aracê, Paulistinha, Maratanã, Costela-de-Vaca and Canapu-Branco) and two levels of osmotic potential induced by PEG $6000(0.0 \mathrm{MPa}$ (control) and $-0.4 \mathrm{MPa})$ in four replicates of 50 seeds. The variables analysed were germination, germination first count, root and shoot lengths, and dry matter accumulation of shoots and roots. The dissimilarity between the genotypes was also determined by Euclidean distance. Germination and initial development of cowpea cultivars are impaired by the reduction in the potential to $-0.4 \mathrm{MPa}$. The cultivars BRS Guariba, BRS Aracê, Paulistinha and Canapu-Branco are the most tolerant to water stress, while BRS Potengi, BRS Itaim, BRS 17 Gurguéia, BRS Maratanã and Costela-de-Vaca are the most sensitive in the early development stage.
\end{abstract}

\section{Palavras-chave:} crescimento inicial polietileno glicol potencial osmótico

\section{Germinação e tolerância de cultivares de feijão-caupi (Vigna unguiculata) ao estresse hídrico}

\begin{abstract}
R E S U M O
Objetivou-se avaliar neste estudo a tolerância de cultivares de feijão-caupi submetidas ao estresse hídrico, durante a germinação e estabelecimento da plântula. Para isso, utilizou-se o delineamento experimental inteiramente casualizado em esquema fatorial constituído de nove cultivares de feijão-caupi (BRS Guariba; BRS Potengi; BRS Itaim; BRS 17 Gurguéia; BRS Aracê; Paulistinha; Maratanã; Costela-de-Vaca e Canapu-Branco) e dois níveis de potencial osmótico induzidos por PEG 6000 [0,0 MPa (controle) e -0,4 MPa], em quatro repetições de 50 sementes. As variáveis analisadas foram a germinação, primeira contagem de germinação, comprimentos da radícula e da parte aérea, acúmulos de massa seca das partes aérea e radícula, e, também, determinou-se a dissimilaridade entre os genótipos por meio da distância Euclidiana. As cultivares de feijão-caupi têm a germinação e o desenvolvimento inicial de plântulas prejudicado pela redução do potencial a - $0,4 \mathrm{MPa}$. As cultivares BRS Guariba, BRS Aracê, Paulistinha e Canapu-Branco são mais tolerantes ao estresse hídrico, enquanto que o BRS Potengi, BRS Itaim, BRS 17 Gurguéia, BRS Maratanã e Costela-de-Vaca são mais sensíveis na fase inicial de desenvolvimento.
\end{abstract}




\section{INTRODUCTION}

Cowpea (Vigna unguiculata (L.) Walp) is a leguminous species of great social-alimentary importance in underdeveloped regions of the world, especially in areas of arid and semi-arid climate, due to the high protein content in its seeds (Akande, 2007; Matos Filho et al., 2009). In Brazil, the expressive cultivation of cowpea is mainly located in the North and Northeast regions, and currently is in expansion in the Mid-West region, arousing the interest of farmers that practice business agriculture (Freire Filho et al., 2011).

Despite the great adaptability of cowpea to the different climate and soil conditions, abiotic stresses are the main factors limiting its production (Matos Filho et al., 2009; Dutra et al., 2015; Souza et al., 2016). In this case, water deficit has been the main factor responsible for the reduction in the production, especially in the Brazilian semi-arid region (Brito et al., 2012).

For seed germination to occur, a satisfactory water potential is required, promoting imbibition and thus activation of metabolism, which directly and indirectly act on seed germination (Colman et al., 2014; Marcos Filho, 2015). In cases of absence, inhibition or reduction in seed imbibition capacity caused by water stress, germination will be compromised and will negatively influence the initial development and production of crops (Guimarães et al., 2008; Souza et al., 2016).

Considering that water deficit is a characteristic inherent to arid and semi-arid regions, it is important to adopt strategies of coexistence with the drought, such as irrigation and identification of materials tolerant to this abiotic stress, to make cultivation viable in these regions (Sá et al., 2016). Therefore, this study aimed to evaluate the tolerance of cowpea cultivars subjected to water stress, during germination and seedling establishment.

\section{Material AND Methods}

The experiment was carried out at the Laboratory of Seed Analysis of the Federal Rural University of the Semi-Arid Region (UFERSA), in Mossoró-RN, Brazil ( $5^{\circ} 11^{\prime}$ S; 37 $20^{\prime} \mathrm{W}$; $18 \mathrm{~m}$ ), from August to November 2016, using seeds of cowpea cultivars, six from the Genetic Improvement Program of Embrapa Semiarido and three usually cultivated in the region.

Nine cowpea cultivars (BRS Guariba; BRS Potengi; BRS Itaim; BRS 17 Gurguéia; BRS Aracê; Paulistinha; BRS Maratanã; Costela-de-Vaca and Canapu-Branco) were subjected to two levels of osmotic potential induced by PEG 6000 [0.0 MPa (control) and $-0.4 \mathrm{MPa}$ ], forming a $9 \times 2$ factorial scheme, and the resulting treatments were arranged in a completely randomized design with four replicates of 50 seeds per plot.

The osmotic potential levels were chosen based on initial pre-tests, in such a way to obtain a control level and a level that exerted selection pressure. The PEG 6000 solution was produced according to the values proposed by Villela et al. (1991) to simulate the preestablished osmotic levels of 0.0 and - $0.4 \mathrm{MPa}$.

Seeds were planted in paper towel roll (Germitest ${ }^{\circ}$ ), moistened with a volume equivalent to 2.5 times its dry weight, and placed to germinate in Biochemical Oxygen Demand (B.O.D) chamber at $25^{\circ} \mathrm{C}$, under photoperiod of $8 \mathrm{~h}$ light and $16 \mathrm{~h}$ dark. Counts were carried out on the fourth and eighth days after sowing, and the results were expressed in percentage of normal seedlings (Brasil, 2009).

At the end of the germination test, the primary root and shoots of normal seedlings of each replicate were measured using a millimeter ruler, and the results were expressed in $\mathrm{cm}$ seedling ${ }^{-1}$. To determine shoot and root dry matter, the seedlings were cut and placed in Kraft paper bags, dried in forced-air oven at $65^{\circ} \mathrm{C}$ until constant weight and weighed on analytical scale $(0.0001 \mathrm{~g})$, and the results were expressed in 'g seedling ${ }^{-1}$ ' (Nakagawa, 1999).

The obtained data were subjected to analysis of variance by $\mathrm{F}$ test and, in cases of significance, the Scott-Knott means grouping test was applied to the factor genotypes and Student's t-test was applied to the factor osmotic potential levels, both at 0.05 probability level, using the statistical program Sisvar ${ }^{\otimes}$ (Ferreira, 2011). The data were subjected to standardization to have mean equal to zero $(\mathrm{X}=0)$ and variance equal to one $(\sigma$ $=1$ ). Then, cluster analysis was carried out using a hierarchical method, Ward's minimum variance, considering the Euclidean distance as measure of dissimilarity (Hair et al., 2009).

\section{Results AND Discussion}

The interaction between cultivars and osmotic potential levels had significant effect $(p<0.05)$ on germination, germination first count and shoot length. Root length was significantly influenced $(\mathrm{p}<0.05)$ by the isolated factors, cultivars and osmotic potential levels. For shoot and root dry matter, only the osmotic potential had significant effect ( $\mathrm{p}<$ 0.05) (Table 1).

For the first count, low values of germination were observed for the cultivars BRS Potengi, BRS Itaim, Paulistinha, BRS Maratanã and Costela-de-Vaca with the reduction in the osmotic potential from 0.0 to $-0.4 \mathrm{MPa}$. At the end of the germination test, some genotypes that had shown low

Table 1. Summary of analysis of variance by $F$ test for the variables: germination first count (FC), germination (G), shoot length $(\mathrm{SL})$, root length $(\mathrm{RL})$, shoot dry matter (SDM) and root dry matter (RDM) of seedlings of cowpea cultivars under water stress in the germination stage

\begin{tabular}{|c|c|c|c|c|c|c|c|}
\hline \multirow{2}{*}{ SV } & \multirow{2}{*}{ DF } & \multicolumn{6}{|c|}{ F test significance } \\
\hline & & FC & $\bar{G}$ & SL & $\mathbf{R L}$ & SDM & RDM \\
\hline Potentials (P) & 1 & * & * & * & * & * & * \\
\hline Cultivars (C) & 8 & * & * & * & * & ns & $\mathrm{ns}$ \\
\hline$P \times C$ & 8 & * & * & * & ns & ns & ns \\
\hline Error & 54 & 83.77 & 59.55 & 0.68 & 1.71 & 88.14 & 81.21 \\
\hline CV (\%) & & 12.88 & 8.97 & 16.15 & 14.97 & 10.12 & 11.83 \\
\hline
\end{tabular}

*Significant at 0.05 probability level; ns - Not significant; CV - Coefficient of variation 
germination in the first count stood out, such as Paulistinha and BRS Maratanã, which were the materials with highest germination percentage under water deficit conditions, along with the genotypes BRS Guariba, BRS 17 Gurguéia and BRS Aracê, for which germination percentages were above $80 \%$, indicating higher tolerance of these materials to water stress in the germination stage (Table 2).

Absence of a satisfactory water potential inhibits or reduces seed imbibition capacity, limiting the activation of the metabolism that acts directly and indirectly on seed germination; consequently, this event is compromised (Guimarães et al., 2008; Colman et al., 2014; Marcos Filho, 2015).

Water deficit simulation using PEG 6000 also allowed to observe the effects of stress on germination and initial growth of seedlings of the cowpea cultivar BRS Tumucumaque, by the reduction in the evaluated variables (Ferreira et al., 2017).

For shoot or hypocotyl length, water stress (-0.4 MPa) drastically limited the growth of all materials studied (Table 2 ). In the control treatment, all cultivars showed good performance, with mean lengths ranging from 6.53 to $13.90 \mathrm{~cm}$, especially the genotypes BRS Guariba, BRS Potengi, BRS 17 Gurguéia, Paulistinha and Canapu-Branco, which showed the highest values of shoot length (Table 2).

Water stress can affect not only imbibition, but also germination, besides causing reductions in seedling growth and development due to the decline in cell expansion (Oliveira et al., 2014; Taiz et al., 2015). Shoot growth reduction may be related to unsatisfactory imbibition, which inhibits enzymatic activity and, consequently, limits the degradation of reserves, maintaining the hypocotyl reduced and the cotyledons virtually intact, as observed in the present study. Thus, water restriction may have caused restrictions in the source-sink relationship, limited hypocotyl growth, reduced the power of the sink organ and, consequently, the degradation of reserves in the source organs (Voigt et al., 2009; Sá et al., 2017).

The cultivars BRS Aracê (5), Paulistinha (6), BRS Maratanã (7) and Canapu-Branco (9) had the highest values of root length, which indicates that these cultivars potentially invested in root system development, especially BRS Maratanã, which showed low value of shoot length in comparison to the other materials tested. It can also be inferred that the genotypes BRS Guariba, BRS Potengi and BRS 17 Gurguéia had greater investment in shoot development, compared with the root system, given the low values of root length and high values of shoot length (Table 2, Figure 1A and B).
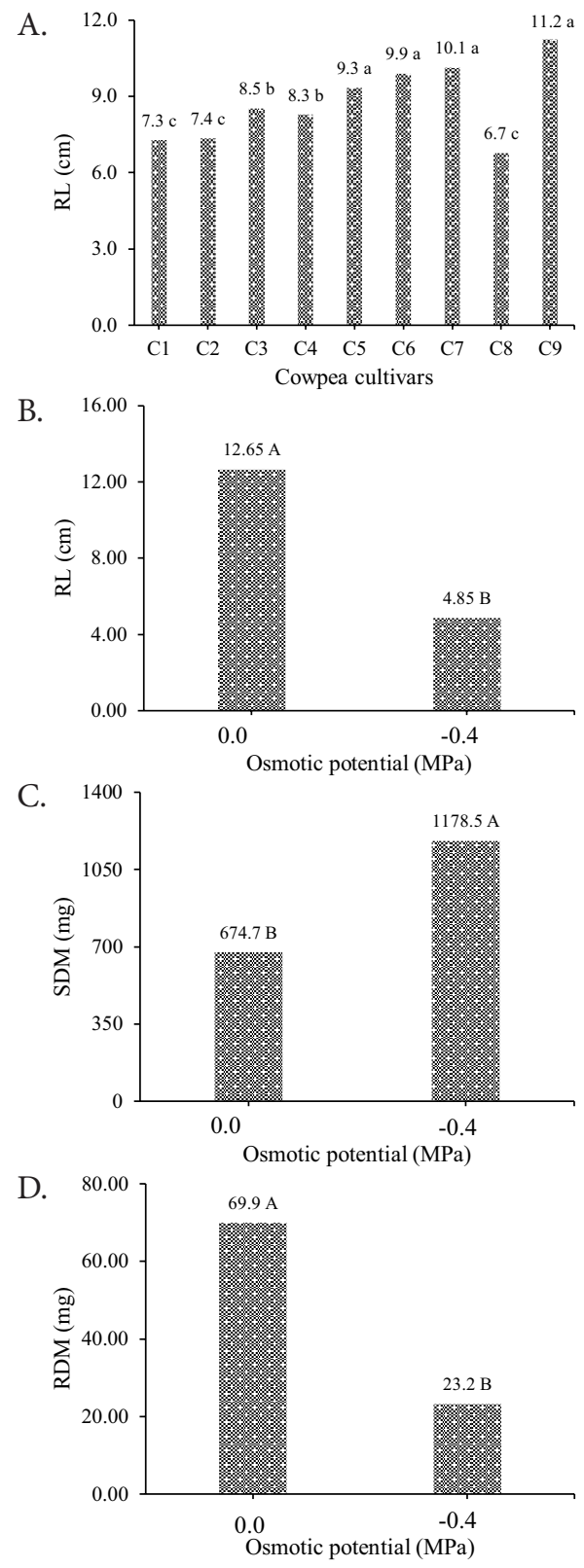

Means followed by the same lowercase letters in the column do not differ by Scott-Knott test and means followed by the same uppercase letters in the row do not differ by t-test, both at 0.05 probability level

Figure 1. Root length (RL) (A and B), shoot dry matter (SDM) (C) and root dry matter (RDM) (D) of seedlings of cowpea cultivars (C1 - BRS Guariba; C2 - BRS Potengi; C3 - BRS Itaim; C4 - BRS 17 Gurguéia; C5 - BRS Aracê; C6 - Paulistinha; C7 - BRS Maratanã; C8 - Costela-de-Vaca and C9 - Canapu-Branco) under water stress

Table 2. Mean values of germination first count (FC), germination (G) and shoot length (SL) of seedlings of cowpea cultivars under water stress

\begin{tabular}{|c|c|c|c|c|c|c|}
\hline \multirow{2}{*}{ Cultivars } & \multicolumn{2}{|c|}{ FC (\%) } & \multicolumn{2}{|c|}{ G (\%) } & \multicolumn{2}{|c|}{ SL (cm) } \\
\hline & $0.0 \mathrm{MPa}$ & $-0.4 \mathrm{MPa}$ & $0.0 \mathrm{MPa}$ & $-0.4 \mathrm{MPa}$ & $0.0 \mathrm{MPa}$ & $-0.4 \mathrm{MPa}$ \\
\hline 1 - BRS Guariba & $97 \mathrm{aA}$ & $73 \mathrm{aB}$ & $99 \mathrm{aA}$ & $89 \mathrm{aA}$ & $9.45 \mathrm{bA}$ & $1.35 \mathrm{aB}$ \\
\hline 2 - BRS Potengi & $99 \mathrm{aA}$ & $43 \mathrm{cB}$ & $100 \mathrm{aA}$ & $70 \mathrm{bB}$ & $10.30 \mathrm{bA}$ & $0.98 \mathrm{aB}$ \\
\hline 3 - BRS Itaim & $81 \mathrm{aA}$ & $38 \mathrm{cB}$ & $81 \mathrm{bA}$ & $67 \mathrm{bB}$ & $8.35 \mathrm{cA}$ & $0.93 \mathrm{aB}$ \\
\hline 4 - BRS 17 Gurguéia & $98 \mathrm{aA}$ & $73 \mathrm{aB}$ & $98 \mathrm{aA}$ & $87 \mathrm{aB}$ & $13.90 \mathrm{aA}$ & $1.08 \mathrm{aB}$ \\
\hline 5 - BRS Aracê & $96 \mathrm{aA}$ & $60 \mathrm{bB}$ & $96 \mathrm{aA}$ & $84 \mathrm{aB}$ & $8.58 \mathrm{cA}$ & $1.14 \mathrm{aB}$ \\
\hline 6 - Paulistinha & $100 \mathrm{aA}$ & $36 \mathrm{cB}$ & $100 \mathrm{aA}$ & $82 \mathrm{aB}$ & $9.05 \mathrm{bA}$ & $0.75 \mathrm{aB}$ \\
\hline 7 - BRS Maratanã & $98 \mathrm{aA}$ & $35 \mathrm{cB}$ & $100 \mathrm{aA}$ & $81 \mathrm{aB}$ & $7.73 \mathrm{cA}$ & $0.93 \mathrm{aB}$ \\
\hline 8 - Costela-de-Vaca & $93 \mathrm{aA}$ & $6 \mathrm{~dB}$ & $95 \mathrm{aA}$ & $56 \mathrm{bB}$ & $6.53 \mathrm{dA}$ & $0.53 \mathrm{aB}$ \\
\hline 9 - Canapu-Branco & $100 \mathrm{aA}$ & $53 \mathrm{bB}$ & $100 \mathrm{aA}$ & $63 \mathrm{bB}$ & $9.75 \mathrm{bA}$ & $0.93 \mathrm{aB}$ \\
\hline
\end{tabular}

Means followed by the same lowercase letters in the column do not differ by Scott-Knott test and means followed by the same uppercase letters in the row do not differ by t-test, both at 0.05 probability level 


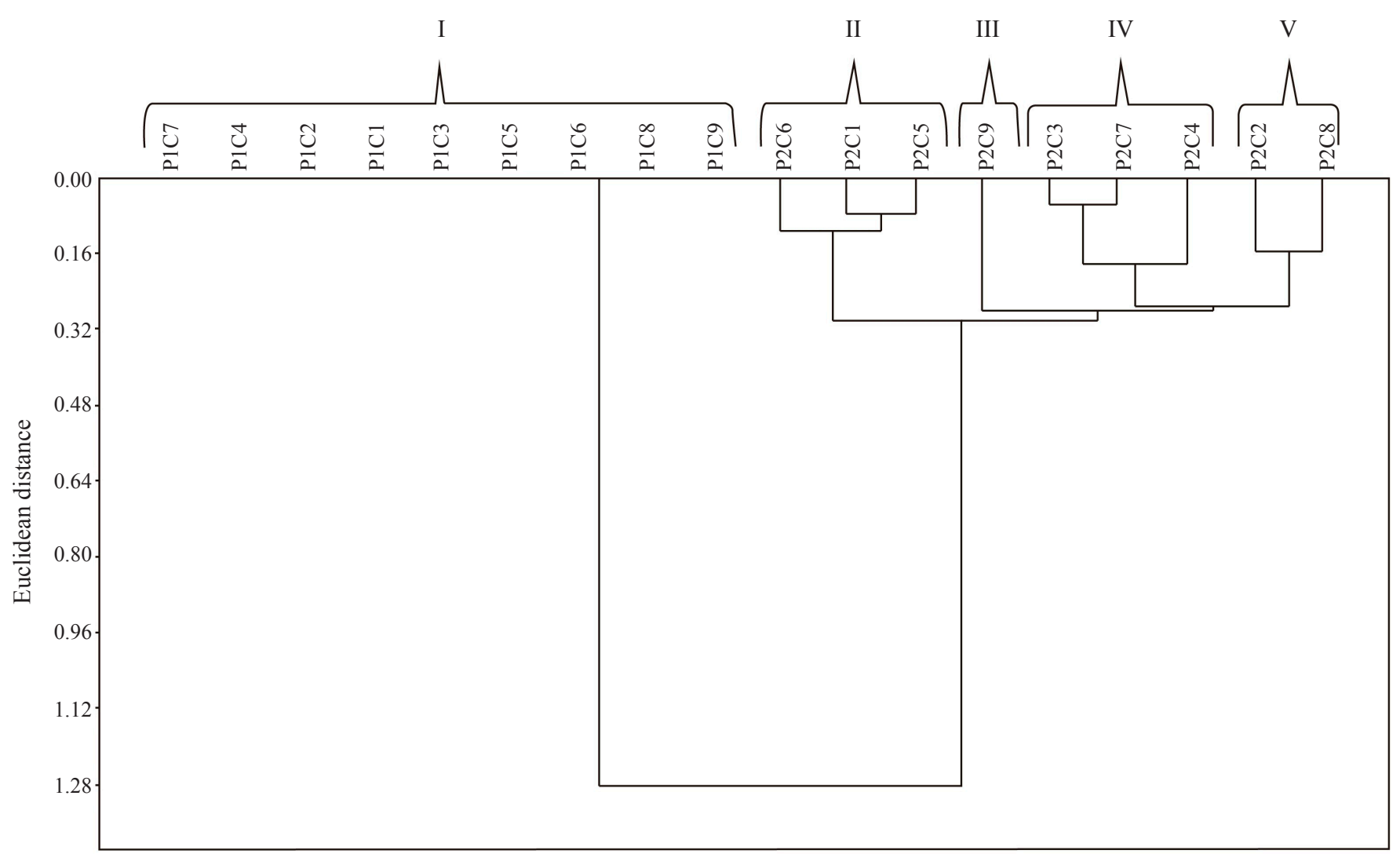

Figure 2. Dendrogram of dissimilarity for the groups formed by the combination of cowpea cultivars (C1 - BRS Guariba; C2 - BRS Potengi; C3 - BRS Itaim; C4 - BRS 17 Gurguéia; C5 - BRS Aracê; C6 - Paulistinha; C7 - BRS Maratanã; C8 Costela-de-Vaca and C9 - Canapu-Branco) and osmotic potential levels (P1 - 0.0 MPa (control) and P2 - -0.4 MPa)

Reduction in the osmotic potential to -0.4 MPa drastically affected radicle development in cowpea seedlings, causing declines of 61.66 and $66.85 \%$ in root length and root dry matter accumulation, respectively (Figures $1 \mathrm{~B}$ and $\mathrm{D}$ ). In the germination of Phaseolus vulgaris under water stress, Coelho et al. (2010), Garcia et al. (2012) and Carvalho et al. (2013) observed that the reduction in osmotic potential substantially reduced root development and, consequently, phytomass accumulation. These authors attributed this effect to the decrease in seed hydration, since water constitutes the matrix for the occurrence of biochemical and physiological processes, which culminate in radicle protrusion.

Shoot dry matter of cowpea showed a different behavior from that of root dry matter, so that seedlings subjected to osmotic potential of - $0.4 \mathrm{MPa}$ obtained higher SDM compared with those under $0.0 \mathrm{MPa}$ (Figure 1C). Since approximately 80 to $95 \%$ of fresh matter in a plant is composed of water (Taiz et al., 2015), seedlings in the control treatment degraded their reserves and, therefore, germinated and developed satisfactorily. On the other hand, seedlings under stress (-0.4 $\mathrm{MPa}$ ) showed lower weight and were less developed (Figure 1C). This result confirms that seed imbibition in the -0.4 $\mathrm{MPa}$ treatment was not satisfactory to efficiently activate the metabolism of the germination process, corroborating the results for germination percentage and shoot length (Table 2), characterizing the $-0.4 \mathrm{MPa}$ level as critical for germination and initial development of cowpea seedlings, limiting imbibition and degradation of seed reserves.

The cluster analysis, based on the Euclidean distance as measure of dissimilarity, revealed the formation of five different groups among the combinations of osmotic potential levels (P) and cowpea cultivars (C) (Figure 2).

Group I contains the cultivars in the absence of water stress, i.e., the genotypes with maximum germination, growth and phytomass accumulation. Groups II and III comprise the cultivars under water stress with the best levels of germination, growth and phytomass accumulation, namely, BRS Guariba, BRS Aracê, Paulistinha and Canapu-Branco, the most tolerant to water stress among the materials tested. Groups IV and V contain the genotypes with lower performance under water stress, BRS Potengi, BRS Itaim, BRS 17 Gurguéia, BRS Maratanã and Costela-de-Vaca, which were the most sensitive to water stress in the stages of germination and initial development of seedlings (Figure 2).

\section{Conclusions}

1. Germination and initial development of cowpea cultivars are hampered by the reduction in the potential to $-0.4 \mathrm{MPa}$.

2. The cultivars BRS Guariba, BRS Aracê, Paulistinha and Canapu-Branco are the most tolerant to water stress, whereas BRS Potengi, BRS Itaim, BRS 17 Gurguéia, BRS Maratanã and Costela-de-Vaca are the most sensitive in the initial development stage.

\section{ACKNOWLedgments}

To Embrapa Semiarido for providing part of the genotypes studied. 


\section{Literature Cited}

Akande, S. R. Genotype by environment interaction for cowpea seed yield and disease reactions in the forest and derived savanna agro-ecologies of south-west Nigeria. American-Eurasia Journal of Agricultural and Environmental Science, v.2, p.163-168, 2007.

Brasil. Ministério da Agricultura, Pecuária e Abastecimento. Regras para análise de sementes. Ministério da Agricultura, Pecuária e Abastecimento. Secretaria de Defesa Agropecuária. Brasília, DF: MAPA/ACS, 2009. 395p.

Brito, L. T. de L.; Cavalcanti, N. de B.; Silva, A. de S.; Pereira, L. A. Produtividade da água de chuva em culturas de subsistência no Semiárido Pernambucano. Engenharia Agrícola, v.32, p.102-109, 2012. https://doi.org/10.1590/S0100-69162012000100011

Carvalho, T. C. de; Silva, S. S. da; Silva, R. C. da; Panobianco, M.; Mógor, A. F. Influência de bioestimulantes na germinação e desenvolvimento de plântulas de Phaseolus vulgaris sob restrição hídrica. Revista de Ciências Agrárias, v.36, p.199-205, 2013.

Coelho, D. L. M.; Agostini, E. A. T. de; Guaberto, L. M.; Machado Neto, N. B.; Custódio, C. C. Estresse hídrico com diferentes osmóticos em sementes de feijão e expressão diferencial de proteínas durante a germinação. Acta Scientiarum. Agronomy, v.32, p.491-499, 2010. http://dx.doi.org/10.4025/actasciagron.v32i3.4694

Colman, B. A.; Nunes, C. M.; Masson, G. de L.; Barbosa, R. H.; Nunes, A. da S. Indução de tolerância ao estresse hídrico na germinação de sementes de feijão-caupi. Comunicata Scientiae, v.5, p.449-455, 2014.

Dutra, A. F.; Melo, A. S. de; Filgueiras, L. M. B.; Silva, A. R. F. da; Oliveira, I. M. de; Brito, M. E. B. Parâmetros fisiológicos e componentes de produção de feijão-caupi cultivado sob deficiência hídrica. Revista Brasileira de Ciências Agrária, v.10, p.189-197, 2015. https://doi.org/10.5039/agraria.v10i2a3912

Ferreira, A. C. T.; Felito, R. A.; Rocha, A. M. da; Carvalho, M. A. C. de; Yamashita, O. M. Water and salt stresses on germination of cowpea (Vigna unguiculata cv. BRS Tumucumaque) seeds. Revista Caatinga, v.30, p.1009-1016, 2017. https://doi.org/10.1590/198321252017v30n422rc

Ferreira, D. F. Sisvar: A computer statistical analysis system. Ciência e Agrotecnologia, v.35, p.1039-1042, 2011. https://doi.org/10.1590/ S1413-70542011000600001

Freire Filho, R. R.; Ribeiro, V. Q.; Rocha, M. M.; Silva, K. J. D.; Rocha, M. S.; Rodrigues, E. V. Feijão-caupi no Brasil: Produção, melhoramento genético, avanços e desafios. Teresina: Embrapa Meio-Norte, 2011. 84p.

Garcia, S. H.; Rozzetto, D. S.; Coimbra, J. L. M.; Guidolin, A. F. Simulação de estresse hídrico em feijão pela diminuição do potencial osmótico. Revista de Ciências Agroveterinárias, v.11, p.35-41, 2012.
Guimarães, M. de A.; Dias, D. C. F. dos S.; Loureiro, M. E. Hidratação de sementes. Trópica, v.2, p.31-39, 2008.

Hair, J. F.; Black, W. C.; Babin, B. J.; Anderson, R. E.; Tatham, R. L. Análise multivariada de dados. 6.ed. Porto Alegre: Bookman, 2009. 688p.

Marcos Filho, J. Fisiologia de sementes de plantas cultivadas. 2.ed. Londrina: Abrates, 2015. 660p.

Matos Filho, C. H. A.; Gomes, R. L. F.; Rocha, M. M.; Freire Filho, F. R.; Lopes, A. C. de A. Potencial produtivo de progênies de feijãocaupi com arquitetura ereta de planta. Ciência Rural, v.39, p.348354, 2009. https://doi.org/10.1590/S0103-84782009000200006

Nakagawa, J. Testes de vigor baseados no desempenho das plântulas. In: Krzyzanoski, F. C.; Vieira, R. D.; França Neto, J. B. (ed.). Vigor de sementes: Conceitos e testes. Londrina: Abrates, 1999. p.2.1-2.24.

Oliveira, E. A. de P.; Zucareli, C.; Prete, C. E. C.; Zamuner, D. Potencial osmótico do substrato na germinação de sementes e desenvolvimento inicial de plântulas de milho doce. Revista Brasileira de Ciências Agrárias, v.9, p.477-482, 2014. https://doi. org/10.5039/agraria.v9i4a2625

Sá, F. V. da S.; Nascimento, R. do; Pereira, M. de O.; Borges, V. E.; Guimarães, R. F. B.; Ramos, J. G.; Mendes, J. da S.; Penha, J. L. da. Vigor and tolerance of cowpea (Vigna unguiculata) genotypes under salt stress. Bioscience Journal, v.33, p.1488-1494, 2017. https://doi.org/10.14393/BJ-v33n6a2017-37053

Sá, F. V. da S.; Paiva, E. P. de; Torres, S. B.; Brito, M. E. B.; Nogueira, N. W.; Frade, L. J. G.; Freitas, R. M. O. de. Germination and vigor of cowpea cultivar seeds under salt stress. Comunicata Scientiae, v.7, p.450-455, 2016. https://doi.org/10.14295/cs.v7i4.1541

Souza, T. M. A. de; Souto, L. S.; Dutra Filho, J. de A.; Sá, F. V. da S.; Oliveira Neto, H. T. de; Paiva, E. P. de; Souza, A. dos S. Cowpea growth and production under different levels of available water and soil cover. International Journal of Current Research, v.8, p.39122-39126, 2016.

Taiz, L.; Zeiger, E.; Møller, I. M.; Murphy, A. Plant physiology and development. 6.ed. New York: Sinauer Associates, 2015. 761p.

Villela, F. A.; Doni Filho, L.; Sequeira, E. L. Tabela de potencial osmótico em função da concentração de polietileno glicol 6000 e da temperatura. Pesquisa Agropecuária Brasileira, v.26, p.19571968, 1991.

Voigt, E. L.; Almeida, T. D.; Chagasa, R. M.; Ponte, L. F. A; Viégas, R. A.; Silveira, J. A. G. Source-sink regulation of cotyledonary reserve mobilization during cashew (Anacardium occidentale) seedling establishment under $\mathrm{NaCl}$ salinity. Journal of Plant Physiology, v.166, p.80-89, 2009. https://doi.org/10.1016/j.jplph.2008.02.008 